
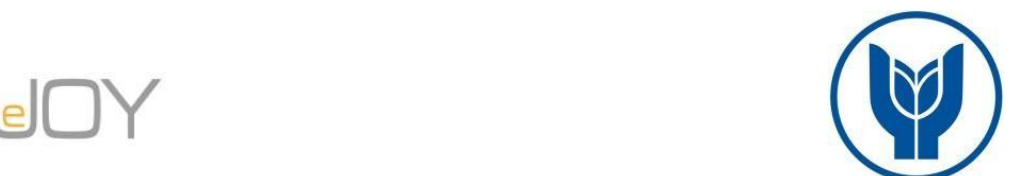

Turan Batuk, S. / Journal of Yasar University, 2018, 13/49, 101-111

\title{
Yapısal Güçlendirme: Bir Ölçek Geliştirme Çalışması
}

\author{
Structural Empowerment: A Scale Development Study
}

Sevgin BATUK TURAN, Türk-Alman Üniversitesi, İstanbul, batukturan@tau.edu.tr

Öz: Güçlendirme kavramı değişen iş dünyası dinamikleri ile birlikte gittikçe önem kazanmaya başlamış bir olgudur. Çalışanların yetkilendirilmesi ve karar süreçlerine dahil edilmesi çalışan verimliliği ve motivasyonunu arttırmada büyük rol oynamaktadır. Bu çalışmada, yapısal güçlendirme kavramının ölçümüne yönelik bir ölçek geliştirmek hedeflenmektir. Bu bağlamda, yürütülen nitel ve nicel analizlerle yeni bir yapısal güçlendirme ölçeği ortaya konulmakta ve ölçek geliştirme metodolojisi anlatılmaktadır.

Anahtar Sözcükler: Güçlendirme, Yapısal Güçlendirme, Ölçek Geliştirme, Çoklu Özellik Çoklu Yöntem Matrisi

Abstract: Enpowerment concept has begun to gain importance in accordance with the changing work environment. Authorizing employees and involving them in decision-making processes have a great role in increasing employee productivity and motivation. In this study, it is aimed to develop a scale to measure structural empowerment. In this respect, with the qualitative and quantitative analyses conducted, a new structural empowerment scale is presented and the scale development methodology is explained.

Keywords: Empowerment, Structural Empowerment, Scale Development, Multi Trait Multi Method Matrix

\section{Giriş}

1900’lü yılların ortalarına kadar organizasyonlar insan faktörü yerine yalnızca üretime önem vermekte ve süreçler yerine sonuçlara odaklanmaktaydı. Günümüzde, "sosyal insan” düşüncesinin bir sonucu olarak, işletmelerde "birey" ön plana çıkmaktadır. Çalışan tatmini ve motivasyonu, üretimle ilgili kaygıların önüne geçmiştir, çünkü, çalışan tatmini ve üretkenlik arasında pozitif bir ilişki olduğu ortaya çıkmıştır. Bu nedenle, organizasyonlar ve üst yönetim çalışan esenliği sağlamak için çalışanların ihtiyaçlarını karşılamaya odaklanmaya başlamıştır.

Özellikle Hawthorne çalışmalarının bireyler arası ilişsilere, iletişime ve çalışanların kararlara katılımı gibi konulara dikkat çekmesinin ardından, organizasyonlarda, "güçlendirme" gibi kavramlar ilgi odağı haline gelmiştir. Çalışanları baskı oluşturmadan yönlendirebilmek için, liderler ellerindeki gücü nasıl yöneteceklerini bilmelidir. Günümüzde, organizasyonların varlıklarını sürdürebilmeleri için, gücü kullanan değil paylaşan yöneticiler gerekmektedir. Gücü paylaşmak, yetki devri ve güçlendirme kavramlarıyla doğrudan ilişkilidir. Güçlendirme daha mutlu ve üretken çalışanlar yaratmanın bir yolu olarak görülmektedir. Literatürde, güçlendirme ile çalışan performansı ve işe adanmışlık gibi olumlu iş davranışları arasında anlamlı bir ilişki olduğu belirtilmektedir (örn. Çöl 2008; Greco vd. 2006). Bu nedenle, güçlendirme kavramını anlamak ve doğru biçimde uygulamak varlıklarını sürdürmek isteyen organizasyonlar için kaçınılmaz hale gelmektedir.

$\mathrm{Bu}$ araştırmanın amacı, güçlendirme kavramına yönelik literatürü nitel ve nicel çalışmalarla harmanlayarak, kavramın ölçümü için yeni bir ölçek geliştirmektir. Bu bağlamda, öncelikle kısa bir literatür taramasına yer verilecek ve ardından yapılan nitel çalışmalara değinilecektir. Akabinde, bu veriler 1şı̆̆ında oluşturulan anketin sonuçları tartışılacak ve ölçeğin geçerliliği ve güvenirliği incelenecektir.

\section{Kavramsal Çerçeve}

\subsection{Güçlendirme Kavramı}

Güçlendirme kavramı artan rekabet koşullarında önem kazanan kavramlardan biri haline gelmeye başlamıştır ve organizasyonların varlıklarını devam ettirebilmek adına başvurduğu önemli araçlardan biridir (Spreitzer vd. 1997). Küreselleşmeyle birlikte hiyerarşik ve dikey örgüt yapılarının değişen çevre koşullarına adaptasyon sorunları yaşamaya başladığı gözlemlenmektedir. Bu nedenle, değişime ve değişimin dinamiklerine ayak uydurabilmek için organizasyonlar daha yatay örgütlenmeler benimsemeye başlamıştır. Bu çeşit yapılanmalar, çalışanlara kararlara katılım gibi imkanlar sağladığı için organizasyonlar için de taklit edilemez bir rekabet avantajı sağlamıştır. Yatay organizasyonlarda çalışanlar kendilerini ifade edebilme imkanı bulmakta ve bu ilişki hem çalışan hem de organizasyon için olumlu sonuçlar doğurmaktadır. Bu sebeple, çalışanlara özerk alanlar yaratan ve karar verme süreçlerinde fikirlerine başvurulmasını öngören güçlendirme işdünyasının favori kavramlarından biri haline gelmiştir.

Güçlendirme kavramı literatürde pek çok farklı açıdan ele alınmaktadır. Bu yaklaşımlardan iki tanesi, psikolojik ve yapısal güçlendirme modelleri yaygınlıkla kabul görmektedir. Psikolojik güçlendirme çalışanların algılarına dayanmaktadır; güçlendirme çalışanların kendilerini güçlendirilmiş hissettikleri ölçüde mevcuttur. Öte yandan, ikinci 
yaklaşım olan yapısal güçlendirme ise algılardan çok örgütsel süreçler üzerine temellendirilmiştir. Güçlendirme, yöneticinin çalışana güç devrettiği yönetsel bir süreç olarak görülmektedir. Bu çalışma kapsamında da, güçlendirme, bir "süreç" olarak ele alınmaktadır ve çalışanların algılarından ziyade organizasyonlarda yürütülen faaliyetlere ve uygulamalara odaklanılmaktadır.

Yönetim literatüründe, güçlendirmenin merkezinde, delegasyon ve karar almanın genele yayılması düşüncesi bulunmaktadır (Tandoğan 2002, 18). Cunningham, Hyman ve Baldrig'e (1996) göre güçlendirme, karar verme gücünün, bu güce sahip olmayanları da kapsayacak şekilde yeniden dağıtılması olarak tanımlanabilir. Hales ve Klidas'a (1998) göre ise güçlendirme, gücün yanı sıra, bilginin de astlarla paylaşılması demektir. Genel olarak güçlendirme tanımlarında yetkinin en alt kademeye kadar devredilmesi, çalışanlara potansiyellerini geliştirmelerine yönelik destek verilmesi ve sorumluluğun arttırılması ortak noktalar olarak göze çapmaktadır (Bakan 2004, 100-101). Burada da görüldügü gibi, çalışanlar bu ilişkide genellikle pasif bir durumdadır ve özellikle yapısal güçlendirmede, güçlendirme, yöneticinin eylemlerinin bir sonucu olarak algılanmaktadır. Yöneticiler ise ancak onlara bu esnekliği tanıyan organizasyon yapılarında çalışanlarını güçlendirebilirler. Bu nedenle, yapı dolaylı olarak çalışan davranışını şekillendirmektedir ve çalışanların güçlendirilmiş davranış biçimleri, örgütün onlara sunduğu imkan ve kaynaklarla ilişkilidir.

Belirtilen bu olanaklar, Kanter'in yapısal güçlendirme modelindeki alt boyutları oluşturmaktadır. Bu boyutlar firsat, bilgi, kaynak, destek, resmi güç ve gayrı resmi güç olarak sıralanmaktadır. Resmi güç çalışanın organizasyondaki pozisyonu sonucunda ele ettiği formel esnekliği ve inisiyatifi belirtirken, gayrı resmi güç ise iş arkadaşları ve üstlerle kurulan enformel ilişkilerle ortaya çıkan yetkileri betimlemektedir. Bu iki boyut diğerlerinin öncülü olarak kabul edilmektedir; güç sahibi bireylerin diğer imkanlara erişimi diğer çalışanlara oranla daha kolay olacaktır (Kanter 1977). Diğer dört boyuttan fırsat boyutu örgütteki gelişim olanaklarını, bilgi boyutu çalışanın örgüt içerisinde gerekli bilgiye ulaşabilme derecesini, kaynak boyutu çalışanın ihtiyaç duyduğu zaman ve ekipmanı, destek boyutu ise çalışanın iş çevresinden edindiği geri bildirimin yeterliliğini ele almaktadır.

Güçlendirmenin uygulanması yalnızca buna izin veren organizasyonlarda mümkündür. Bu şu anlama gelmektedir: organizasyonel yapı ve kültür bir örgütteki güçlendirme seviyesinin ana belirleyicileridir. Hamel ve Prahalad'a (2002) göre, hiyerarşiler inisiyatifi ve yaratıcılığı öldürmektedir ve bu nedenle de hiyerarşik yapılarda güçlendirme olanaksızdır. Yapının yanısıra, kültür de güçlendirme için engel oluşturabilir. Güçlendirme faaliyetlerini etkin bir biçimde uygulayabilmek için gözönünde bulundurulması gereken birkaç faktör bulunmaktadır. Dobbs'a (1993) göre, başarılı bir güçlendirme süreci için kaynakların erişilebilir olması, çalışanların yöneticilerle birlikte problem çözüm süreçlerine dahil edilmesi, yeterli eğitim imkanlarının sunulması ve başarının ödüllendirilmesi gerekmektedir.

Görüldüğü gibi, Kanter tarafından belirtilen boyutlar ve Dobbs tarafından özetlenen koşullar genellikle çalışanın kontrolü dışındadır ve organizasyonel süreçlerin sonuçlarıdır. Bu çalışmada amaç, güçlendirmeyi bu bakışla yeniden ele almaktır, ve bu nedenle, ilerleyen bölümlerde, aynı kavramsal çerçeveyi paylaşan çalışmalara yer verilecektir.

\subsection{Güçlendirme ve İlgili Ölçekler}

Daha önce belirtildiği gibi, güçlendirme kavramına pek çok yaklaşım bulunmaktadır ve bu nedenle birçok ölçek geliştirilmiştir. $\mathrm{Bu}$ bölümde çalışmada kullanılan bazı temel ölçeklere ve nasıl kavramsallaştırıldıklarına değinilmektedir.

İlk güçlendirme ölçeği yapısal güçlendirmeyi ölçmek için en çok kullanılan Conditions of Work Effectiveness II (CWEQ-II) (Laschinger vd. 2001) ölçeğidir. Bu ölçek Chandler tarafından (1986) oluşturulan CWEQ ölçeğinin kısaltılmış ve iyileştirilmiş versiyonudur. Ölçeğin Türkçe’ye tercümesi Ton (2008) tarafından yapılmıştır. Bu ölçek yapısal güçlendirme degişkeninin Kanter tarafindan kavramsallaştırılmış olan altı boyutunu (firsat, bilgi, destek, kaynak, resmi güç, gayri resmi güç) ölçen 19 sorudan oluşmaktadır.

Çalışmanın kullandığı ikinci ölçek ise Leslie, Holzhalb ve Holland (1998)'ın Worker Empowerment Scale (WES)'tir. Ölçek geliştirme çalışması, literatür araştırmasından elde edilen 28 soru ile başlamıştır ve 3 alt boyut- kişisel iş oryantasyonu, iş çevresinde kontrol ve iş ilişkileri- şeklinde oluşturulmuştur. Kişisel iş oryantasyonu boyutu, bireyin organizasyon içinde gördüğü değerle ilintili olarak özyeterlilik algısıyla ilgili sorular içerir. İş çevresinde kontrol boyutu bireyin karar verme gücü hakkında sorular ve iş ilişkileri boyutu çalışanlar arası etkileşimin durumsallığı ile ilgili sorular içerir. Pilot çalışmalardan ve faktör analizlerinden sonra 24 sorunun geçerli ve güvenilir bir ölçek oluşturduğu görülmüştür.

Arnold, Arad, Rhoades ve Drasgow’un 2000 yılında yayınlanan makaleleri liderlerin güçlendirme davranışlarına (Empowering Leadership Questionnaire- ELQ) odaklanarak güçlendirmeye yeni bir bakış açısı getirmistir. Ölçek, beş boyuttan oluşmaktadır ve 38 soru içermektedir. Boyutlar, güçlendiren bir liderin sergilediği davranışlar ile ilgilidir; bunlar; örnekle yönlendirme, katılımcı karar verme, koçluk yapma, bilgilendirme ve ekiple ilgilenmedir.

Benzer bir çerçevede geliştirilen bir diğer ölçek ise, Konczak, Stelly ve Trusty (2000) tarafindan geliştirilen ve liderin güçlendirme davranışlarını ölçen Leader Empowering Behavior Questionnaire- LEBQ'dir. Bu çalışmada nomolojik geçerlilik testlerinden ve faktör analizinden sonra altı boyutlu bir model ortaya çıkmıştır. Bu boyutlar, otoritenin delege edilmesi, sorumlu tutulabilme, kendinden yönlendirmeli karar alma, bilgi paylaşma, yetenek geliştirme ve yaratıcı performans için koçluktur. Ölçek 17 ifadeden oluşmaktadır.

Bu çalışmada konu edilen en son ölçek ise Spreitzer (1995) tarafindan geliştirilen Psikolojik Güçlendirme Ölçeği (Psychological Empowerment Scale)'dir. Ana odağımız psikolojik güçlendirme olmasa da kavramın bazı boyutları yapısal güçlendirme ile paralellik göstermekte olduğundan ihmal edilmemelidir. Temelde Thomas ve Velthouse 
(1990)'ın kavramsallaştırması çerçevesinde, Spreitzer, psikolojik güçlendirmenin dört boyutunu yeterlilik (işle ilgili kisisel yeterlilik), etki (iş çıktılarını etkileme becerisi), anlam (bireysel ve örgütsel gollerin örtüşmesi) ve seçim (özerklik ve girişkenlik) olarak belirtmiş̧ir. Ölçek 12 sorudan oluşmaktadır.

Sharma ve Kaur (2011) bir literatür incelemesinden sonra, yapısal güçlendirmeyi oluşturan ana degişkenleri belirlemişlerdir. Çalışmaya göre, kontrol odağı, öz saygı, iş tanımının açıklığı, özerklik, bilgi ve iletişim, ödül sistemleri, organizasyonel iklim ve yetenekler ile bilgi yapısal güçlendirmenin öncelleridir.

Tüm bu ölçeklerdeki bilgiler ve belirtilen güncel araştırmalar bir araya getirildiğinde, çalışanın özerkliği ile birlikte gelen karar verme gücü, çalışanın ulaşabildiği bilgi, bilgi elde etme ve yeni yetenekler geliştirme firsatı ve gerekli kaynaklara ulaşım faktörlerinin neredeyse tümünde vurgulandığı görülmektedir. Bu sonuçlar, ilerleyen bölümlerde, kalitatif çalışmaların sonuçları ile bir araya getirilecektir.

\section{Nitel Çalıșmalar}

Bu bölümde, güçlendirme kavramını daha iyi anlayabilmek için kalitatif veri toplama yöntemi olarak iki odak grup mülakatı ve bir derinlemesine mülakat kullanılmıştır. Kalitatif çalışmalar, boyutları netleştirmede ve sorulara karar vermede çok önemli bir rol üstlenmektedir; bu nedenle bu bölümde çalışmalar kısaca anlatılacak ve ilgili sonuçlar verilecektir.

\subsection{Odak Grup Mülakatlart}

Odak grupları kalitatif araştırmalarda, en önemli fikir geliştirme yöntemlerinden biri olarak kabul edilir. Geniş kapsamlı bir ölçek geliştirmek için, odak grup çalışmaları çok faydalı bulunmaktadır çünkü, böylece bir kavramın tüm mevcut boyutları ortaya çıkarılabilmektedir (Morgan 1997).

Örneklemi seçerken ana kaygı grup içi homojenliği ve gruplar arası heterojenliği sağlamaktır. Bu çalışmadaki ilk odak grup İstanbul'da faaliyet veren bir devlet üniversitesinde işletme yüksek lisans öğrenimi gören ve aynı zamanda iş hayatı içerisinde bulunan öğrencilerden oluşmaktadır. Profesyonel tecrübelerinin yanı sıra yönetim terminolojisi ile yakın olduklarından ve teorik temelleri olduğundan odak grup mülakatı sonucunda faydalı bilgiler elde edilmiştir. Çalışma kampüste bir sınıfta yapılmıştır ve yaklaşık 45 dakika sürmüştür. Çalışma Türkçe yapılmıştır fakat bazı terimler İngilizce olarak kullanılmış ve kayda alınmıştır. Grubun ortalama yaşı 27 'dir ve yaş dağılımı 24 ile 31 arasındadır. Katılımcıların ikisi bayan dört tanesi ise erkektir.

Çalışmaya genel bir soru ile başlanmıştır ve katılımcılar gittikçe özele doğru yönlendirilmiştir. Görüşmeyi başlatmak için "Güç’ü nasıl tanımlarsınız?" sorusuyla başlanmıştır ve akabinde "Güçlendirme terimi size ne ifade ediyor?" sorusu sorulmuştur.

Güçlendirmeyi kendi terimleri ile tanımlamalarından sonra bir organizasyon ya da bölüm içerisinde güçlendirme kararı ile ilgili olduğunu düşündükleri faktörleri tartı̧̧maları istenmiş̧ir. Organizasyon içerisinde güçlendirme seviyesini etkileyen faktörleri tartışırlarken, güçlendirmenin önündeki engellere doğru yönlenilmiştir. Son olarak bir organizasyon içerisindeki güçlendirme seviyesini ölçmede nelerin faydalı olabileceği sorulmuştur. Tartışma süresince bir çok ortak başlık belirtilmistir, fakat yeni maddeler de ortaya çıkmıştır. Toplantı, artık fikir üretilmediği görüldüğünde kapatılmıştır.

İkinci odak grup mülakatı İstanbul'da faaliyet veren bir özel üniversitenin İktisat Bölümü'nden mezun 5 özel sektör çalışanından oluşmuştur. 3 bayan ve 2 baydan oluşan grupta, yaslar 25 ile 27 arasında degişmektedir, ortalaması ise 26 'dır. Toplantı süresince, ilk odak grup mülakatına benzer bir süreç izlenmiştir. Toplantı yaklaşık 50 dakika sürmüştür.

Genel olarak, tartışmalar sırasında sıkı kurallar takip edilmemiştir fakat katılımcıların konuya tanıdık olması toplantının yönetilmesini kolaylaştırmıştır ve faydalı bilgiler edinilmesini sağlamıştır.

Odak grup çalışmalarının, genellikle, 6 ile 10 kişi arasında yapılması tavsiye edilmektedir, bu nedenle ikinci gruptaki katılımcı sayısı çalışma için bir kısıttır. Aynı zamanda, Morgan (1997)'a göre en az 3 odak grup gereklidir; fakat elde edilen bilgilerin benzerliği göz önünde bulundurulduğunda ve bu çalışmaların literatür taramasında destek sağlamak amacıyla yapıldığı düşünüldüğünde 2 odak grup yeterli görülebilir. Bu etkiyi en azına indirgemek ve daha fazla bilgi edinebilmek adına, ayrıca, bir derinlemesine mülakat yapılmıştır.

\subsection{Derinlemesine Mülakat}

Mülakat Gebze'de faaliyet gösteren bir otomotiv firmasında proje yöneticisi olarak çalışan ve MBA derecesine sahip olan 33 yaşında bir makina mühendisi ile gerçekleştirilmiştir. Katılımcı ilk seviye yönetici kabul edilebileceğinden güçlendirme konusunda iki yönlü bilgi elde edebilme şansı yakalanmıştır. Benzer sorular sorularak, güçlendirme yapabilen bir yönetici ve güçlendirilebilecek bir çalışan olarak iki yönlü cevaplaması istenmiştir. Bu ikili bakış açısı konunun daha derinlemesine ele alınmasına olanak sağlamıştır. Ayrıca, güçlü bir güçlendirme süreci için hangi kaynakların gerekli olduğu ve güçlendirmenin çalışana neler kattığı sorulmuştur. Mülakat yaklaşık 50 dakika sürmüştür ve kayıt altına alınmıştır. 


\section{4. İfade Geliştirme}

Odak grup mülakatları ve derinlemesine görüşmeden elde edilen veriler içerik analizi ile deşifre edilmiştir. Kalilatif çalışmalar sonucu elde edilen ifadeler ve tekrar sayıları aşağıdaki tabloda (Tablo 1) belirtilmektedir.

Tablo 1. Nitel Çalışmalar İçerik Analizi Sonuçları

\begin{tabular}{|l|l|}
\hline İfade & Sıklık \\
\hline Gerektiğinde üst yönetimle beraber toplantılara katılabiliyorum. & 2 \\
\hline Yöneticilerim işleri kontrol edebilecek yeterliliğe sahip olduğumu düşünür. & 6 \\
\hline İşimde bazen pozisyonumun gerekliliklerinin üstünde görevler yürütüyorum. & 4 \\
\hline İşimin gereklerini yerine getirmem için her türlü kaynak bana sunulur. & 8 \\
\hline İşimde gerekli yerlerde her zaman eğitim desteği sunulur. & 7 \\
\hline Kendi işim hakkında karar verme yetkisine sahibim. & 11 \\
\hline Yöneticim, her ihtiyaç duyduğumda, benimle bilgi paylaşır. & 9 \\
\hline İşim esnasında yeni yetenekler ve beceriler geliştirme imkanına sahibim. & 10 \\
\hline $\begin{array}{l}\text { Devam etmeden önce, en basit kararların bile yöneticiler tarafından kontrol } \\
\text { edilmesi gerekir.* }\end{array}$ & 6 \\
\hline Yöneticim bana gerektiğinde değişiklik yapmam için yetki verir. & 9 \\
\hline İşimi nasıl yapacağım konusunda imtiyaz (özerklik) sahibiyim. & 10 \\
\hline
\end{tabular}

*Olumsuz ifade

Bu adımdan sonra, literatürden alınan ifadeler kalitatif analizler sonucunda elde edilen ifadeler ile birleştirilmiştir. Belirsiz ve ilgisiz gözüken ifadelerin elenmesinin ardından 28 ifadelik bir havuz oluşturulmuştur. Bu aşamada hakem kurulu yöntemine başvurulmuş ve ilgili ifadelerin sınıflandırılması için 2 hakem tayin edilerek destek alınmıştır. Kalan 28 ifadenin değerleyiciler arası güvenilirliğini hesaplamak için, hakemlerin, ifadeleri bir sonraki bölümde belirtilecek olan 5 boyut altına yerleştirmeleri istenmiştir. İlgili 5 boyutun açıklamaları hakemlere verilmiş ve akabinde ifadeleri kategorize etmeleri beklenmiştir. Örgütsel davranış alanında yüksek lisans sahibi ve aynı alanda doktora eğitimini sürdürmekte olan iki öğrenci hakem olarak görevlendirilmiştir. Toplamda, 28 maddeden 24 tanesinin benzer sınıflandırıldığı gözlenmiştir.

Hakemler arası güvenilirliği hesaplamak için Cohen'in Kappa katsayısı kullanılmıştır. Cohen'in Kappa katsayısı iki değerleyici arasındaki uyuşmanın güvenirliliğini ölçmek için kullanılan istatistiksel bir yöntemdir. Bu metod, değerleyiciler arasındaki basit anlaşma yüzdesinin yetersiz bir ölçüm aracı olduğunu belirtmekte ve ifadelerin sinıflandırılmasındaki uyumun şans eseri olabileceğini de göz önünde bulundurmaktadır (Cohen, 1960). Bu nedenle literatürde değerleyiciler arası güvenilirlik ölçümü için sıklıkla tercih edilen yöntemlerden biridir (McHugh, 2012).

Cohen'in Kappa katsayısı (K) aşağıda belirtilen şekilde formülize edilmektedir (Kılıç, 2015):

$\mathrm{K}=[\operatorname{Pr}(\mathrm{a})-\operatorname{Pr}(\mathrm{e})] /[1-(\operatorname{Pr}(\mathrm{e})]$

$\operatorname{Pr}(\mathrm{a})=$ Değerleyiciler arasında gözlemlenen uyumların toplam orantısı

$\operatorname{Pr}(\mathrm{e})=$ Uyumun şansa bağlı olarak ortaya çıkma olasılı̆̆

Kappa katsayısı MATLAB, SPSS gibi paket programlar aracılığı ile de hesaplanabilmektedir. Bu araştırma kapsamında da iki hakem arasındaki uyumun güvenilirliğini ölçmek için bu paket programlardan yararlanılmıştır. Kappa katsayısı hem MATLAB hem de SPSS programları ile hesaplanmış ve değerleyiciler arası uyum güvenilirliğinin 0.81 olduğu görülmüştür. Literatürde, pek çok araştırmacıya göre, 0.80'nin üzerindeki Kappa katsayıları kabul edilir düzeydedir ve yüksek güvenirliliğe işaret etmektedir (örn. Landis ve Koch, 1977; Altman, 1991).

Güvenilirlik katsayısı 0.80 'nin üzerinde olduğu için, hakemlerin hemfikir olmadığı 4 ifade elenerek, çalışmaya kalan 24 ifade ile devam edilmiştir. 


\section{5. Ölçek Geliştirme}

\subsection{Kavramsal Çerçeve}

Bu çalışma kapsamında, Kanter'in yapısal güçlendirme modeli baz alınarak, güçlendirme kavramı 5 boyut üzerine temellendirilmiştir. Kalitatif çalışmalardan elde edilen ifadeler de literatürden gelen bilgiler 1şığında hipotetik olarak bu boyutlara dağıtılmıştır. Hakemlar arasında anlaşma sağlanan ifadeler anket çalışması için korunmuştur. Temel alınan 5 alt boyut şöyle sıralanmaktadır;

1. Resmi Güç (pozisyon gücü ve otonomi)

2. Gayrı Resmi Güç (personelle işbirliği)

3. Bilgiye Erişim

4. Kaynaklara Erişim

5. Gelişim İmkanları

Özetle, yapısal güçlendirmenin bu 5 boyutla şekilleneceği öngörülmektedir.

\subsection{Anket}

Ek 1'de belirtilen 24 ifade ile iki anket oluşturulmuştur. Bu iki anket aynı sorulardan oluşmasına karşın, Çoklu Özellik Çoklu Yöntem Matrisi (The Multitrait-MultiMethod Matrix) oluşturabilmek için farklı ölçekler üzerinden cevaplandırılmıştır.

İlk anket aralık ölçek üzerinden yanıtlanan ifadelerden oluşmaktadır. Cevap seçenekleri "Tamamen Katılıyorum=6" ile "Kesinlikle Katılmıyorum=1" aralığında değişmektedir. İkinci ölçüm ise oran ölçek üzerinden yapılmıştır. Katılımcılar verilen ifadelere ne kadar katıldıklarını "0" ile "100” arasında bir sayı seçerek belirtmişlerdir. Ankete demografik özelliklere yönelik sorular da eklenmiştir. $\mathrm{Bu}$ sorular yaş, cinsiyet, eğitim düzeyi, sektör ve organizasyondaki pozisyona yönelik sorulardır. Bu proje kapsamında, güçlendirme, yöneticinin yürüttüğü bir uygulama olarak ele alındığı için, üst yönetimden olası katılımcıları eleyebilmek için çalışanın pozisyonu özellikle ankete dahil edilmiştir. Bunun yanı sıra, organizasyonun hiyerarşik yapısı hakkında 3 soru ve çalışanın iş tatmini hakkında da 3 soru ankete eklenmiştir. Buradaki amaç, ölçeğin nomolojik geçerliliğini test edebilmektir. Literatürde, güçlendirme ile iş tatmini arasında anlamlı bir ilişki olduğuna işaret eden pek çok çalışma bulunmaktadır (örn. Swenson 1997; Jun ve Lee 2000; Savery ve Luks 2001).

Ölçeklerdeki ifadeler İngilizce'den Türkçe'ye çevrilmiştir. CWEQII ölçeğindeki ifadeler Ton (2008) tarafından Türkçe'ye çevrilmiştir. Diğer ölçeklerden alınan ifadeler ise bir devlet üniversitesinde görev yapmakta olan 2 akademisyen tarafindan önce Türkçe'ye sonra tekrar İngilizce’ye çevrilerek sonuçlar karşılaştırılmıştır.

\section{3. Örneklem}

Kolayda örneklem yoluyla anket internet üzerinde bir bağlantı aracılığıyla çeşitli şirketlerde çalışan katılımcılara dağıtılmıştır. Sonuçta 132 anket toplanmış fakat 3 katılımcının üst yönetici olması dolayısıyla kullanılabilir 129 adet anket elde edilmiştir. Bu sayı güvenilirlik ve geçerlilik testleriyle devam etmek için uygundur.

\section{Veri Analizi}

\subsection{Betimsel İstatistikler ve Ölçeğin Güvenirlik Analizi}

Örneklem incelendiğinde, katılımcıların yaşlarının 23 ile 57 arasında değiştiği ve ortalama yaşın 31 olduğu görülmektedir. Bütün katılımcılar en az üniversite mezunudur ve bu katılımcıların eğitim seviyesinin yüksek olduğunu göstermektedir. Katılımcılardan 44'ü bayan ve 85'i erkektir. 112 katılımcı özel sektörde çalışmakta iken yalnızca 17 kişi kamu sektöründedir. Katılımcıların demografik özelliklerine ilişkin veriler Tablo 2'de verilmektedir.

Tablo 2. Katılımcıların Demografik Özellikleri

\begin{tabular}{|l|l|c|c|}
\hline Özellik & Kategori & Frekans & Yüzde (\%) \\
\hline Cinsiyet & Kadın & 44 & 34 \\
& Erkek & 85 & 66 \\
\hline Yaş & $21-30$ & 49 & 38 \\
& $31-40$ & 36 & 28 \\
& $41-50$ & 31 & 24 \\
& $51-60$ & 13 & 10 \\
\hline Sektör & Kamu & 17 & 13 \\
& Özel & 112 & 87 \\
\hline
\end{tabular}


Yanıtlara bakıldığında, seçenekler arasında normal bir dağılım görülmektedir. Betimleyici istatistikler incelenirken, normallik varsayımları da test edilmiştir, çünkü faktör analizi uygulayabilmek için normal dağılım bir gerekliliktir. Bu nedenle çarpıklık ve basıklık testleri olan kurtosis ve skewness test sonuçlarına bakılmıştır. Bu testlerde 4., 7 . ve 12 . soruların “-1, +1” sınırını geçtikleri görülmüştür ve bu nedenle analiz dışı bırakılmıştır. Ayrıca, faktör analizine geçmeden önce, ölçeğin genel güvenirlik seviyesi ve ifadeler arası korelasyonlar da incelenmelidir.

İfadeler arası korelasyonlar aracılığıyla aynı kavramı ölçen benzer ifadeler ve kavramla ilgisi bulunmayan ifadeler hakkında fikir edinilebilmektedir. Bu aşamada, Pearson korelasyon katsayılarına bakıldığında, 3., 6., 15. ve 20. İfadelerin diğer ifadelerle anlamlı korelasyonu olmadığı gözlenmiştir. Ayrıca, buna paralel olarak, ölçeğin genel güvenirliğine bakıldığında da, bu 4 ifade silindiği takdirde, ölçeğin Cronbach Alfa katsayısının yükseldiği görülmüştür. Ayrıca, şunu belirtmek gereklidir ki, güvenirliği düşüren bu 4 ifadenin tamamı ters kodlanmış, olumsuz sorulardır. (Analizlerden önce bu ifadeler tekrar kodlanarak diğer ifadelerle paralel hale getirilmiştir.) Neteyemer, Bearden and Sharma'ya (2003) göre, pozitif ifadeler negatif ifadelerden daha güvenilir sonuçlar vermektedir; bu nedenle, bu araştırma kapsamında, negatif ifadeler yerine pozitif ifadeler kullanılmış olsaydı, sonuçların farklı çıkabileceğini belirtmek gerekmektedir. Belirtilen ifadeler silindikten sonra, ölçeğin güvenirlik istatistikleri aşağıdaki tabloda (Tablo 3) belirtilmektedir.

Tablo 3. Güvenirlik Analizi

\begin{tabular}{|l|l|}
\hline Cronbach Alfa & İfade Sayısı \\
\hline 0.939 & 17 \\
\hline
\end{tabular}

Analizler sonucunda, Cronbach Alfa güvenirlik katsayısı 939 olarak hesaplanmıştır ve bu katsayı ölçeğin güvenilir olduğunu gösterecek seviyede yüksektir. Faktör analizinden sonra, ortaya çıkan faktörlerin (boyutların) güvenirliğini test etmek için tekrar güvenirlik analizleri yapılacaktır.

\subsection{Faktör Analizi}

Faktör analizi, Asıl Bileşenler (Principal Component) ve Kaiser Normalizasyonu ile Varimax rotasyonu kullanılarak yapılmıştır. İlk seferde, 8. ifadenin yakın değerlerle 2 faktör altında yer aldığı gözlenmiştir ve bu nedenle, 8. İfade analiz dışı bırakılmıştır. Tekrarlanan faktör analizi sonucunda KMO .832 olarak hesaplanmıştır ve Bartlett testi anlamlı çıkmıştır; bu nedenle faktör analizinin geçerli olduğu söylenebilir. Tablo 4'te ifadelerin faktörler altındaki dağılımları ve ağırlıkları görülmektedir.

Tablo 4. Faktör Analizi Sonuçları

\begin{tabular}{|l|c|c|c|c|}
\hline \multirow{2}{*}{ İfadeler } & \multicolumn{4}{|c|}{ Faktörler } \\
\hline & 1 & 2 & 3 & 4 \\
\hline S22 & 0.877 & & & \\
\hline S23 & 0.827 & & & \\
\hline S24 & 0.751 & & & \\
\hline S16 & 0.634 & & & \\
\hline S18 & & 0.747 & & \\
\hline S17 & & 0.713 & & \\
\hline S19 & & 0.694 & & \\
\hline S10 & & 0.674 & & \\
\hline S11 & & 0.581 & & \\
\hline S2 & & & 0.751 & \\
\hline S1 & & & 0.750 & \\
\hline S5 & & & 0.738 & \\
\hline S9 & & & 0.636 & \\
\hline S13 & & & 0.615 & \\
\hline S14 & & & & 0.870 \\
\hline S21 & & & & 0.770 \\
\hline
\end{tabular}


Tablo 4'ten görüleceği üzere, keşifsel faktör analizi sonucunda, ifadeler beklendiği gibi 5 faktör altında değil 4 faktör altında toplanmıştır. Faktörler tarafından açıklanan varyansa bakıldığında, 4 faktörün birlikte varyansın \% 76,98'lik bir kısmını açıkladığı görülmüştür.

İstatistiklerden görüldüğü gibi, 16., 22., 23. ve 24. İfadeler bir faktör altında toplanmıştır. 16. ifade teorik çerçevede beklenilenden farklı bir faktör altında yer almaktadır. "Yöneticim kaliteli sonuçlara ulaşmamı sağlayacak bilgileri benimle paylaşır." ifadesi çalışana sunulan bir gelişim imkanı olarak değerlendirilmiş olabilir; bu nedenle de "Fırsat" boyutu altına yerleşmiş olabilir. İkinci faktör, "Gayrı Resmi Güç”, 10., 11., 17., 18. ve 19. İfadelerden oluşmaktadır ve bu ifadeler kuramlaştırıldığı şekilde yüklenmiștir. Üçüncü faktör 1., 2., 5, 9., ve 13. İfadelerden oluşmaktadır ve bu sonuç beklenildiği gibidir. Bu faktör "Resmi Güç" olarak adlandırılmış olan faktördür. Son faktör ise, "Bilgiye Erişim" ve "Kaynaklara Erişim" boyutlarından birer ifadenin birleşimi olarak ortaya çıkmaktadır. Bu durum 2 şekilde açıklanabilir. Bilginin de bir kaynak olarak algılanmış olması mümkündür ve bu nedenle bilgiye erişim temin edilen bir materyal olarak görülmüş olabilir. İkinci açıklama ise, bu faktörlere ait ifadeler daha önce analiz dışı bırakıldığı için bu iki ifadenin bir araya gelmiş olması ihtimalidir. Sonuç olarak, faktörler birer ifadeden oluşamayacağı için, bu iki ifadeyi beraber ele almak daha doğru olacaktır. İki ifadeden oluşan bu yeni faktöre ise "Bilgi ve Kaynak" ismi verilmiştir.

\subsection{Faktörlerin Güvenirlik Analizleri}

Ölçeğin güvenirliğini test etmek için, faktörlerin de güvenirliklerinin ölçülmesi gerekmektedir. Faktör analizi sonucunda elde edilen 3 faktör için Cronbach Alfa istatistiğine bakılabilir, fakat, Bilgi ve Kaynak faktörü için Pearson Korelasyon İstatistiğine bakılması gerekmektedir çünkü bir faktör yalnızca 2 ifadeden oluşuyorsa, Cronbach Alfa istatistiği güvenirlik ölçümü için kullanılamaz. Aşağıdaki tablolarda, aralık ölçek ve oran ölçeğe göre faktörlerin güvenirlik istatistikleri sunulmaktadır:

Tablo 5. Aralık Ölçek Güvenirlik Analizleri

\begin{tabular}{|c|c|c|c|}
\hline Boyut & İsim & $\begin{array}{c}\text { Güvenirlik } \\
\text { (Cronbach Alfa) }\end{array}$ & $\begin{array}{c}\text { Güvenirlik } \\
\text { (Pearson Korelasyonu) }\end{array}$ \\
\hline 1 & Resmi Güç & 0.878 & - \\
\hline 2 & Gayrı Resmi Güç & 0.865 & - \\
\hline 3 & Bilgi ve Kaynak & 0.844 & 0.737 \\
\hline 4 & Frrsat & 0.906 & - \\
\hline
\end{tabular}

Aralık ölçek için yapılan güvenirlik analizi sonucunda Cronbach Alfa seviyelerinin ifade silerek yükseltilemeyeceği görülmüştür. Peter'a (1979) göre, ölçek geliştirme çalışmalarında güvenirlik istatistiklerinin .5 ve .6 civarında olması yeterlidir ve genellikle .7 üzeri güvenirlik isttaistikleri ideal olarak değerlendirilmektedir. Bu bağlamda, ilk ölçek için bütün istatistiklerin .7 üzerinde olduğu görülmektedir.

Tablo 6. Oran Ölçek Güvenirlik Analizleri

\begin{tabular}{|c|c|c|c|}
\hline Boyut & İsim & $\begin{array}{c}\text { Güvenirlik } \\
\text { (Cronbach Alfa) }\end{array}$ & $\begin{array}{c}\text { Güvenirlik } \\
\text { (Pearson Korelasyonu) }\end{array}$ \\
\hline 1 & Resmi Güç & 0.916 & - \\
\hline 2 & Gayr1 Resmi Güç & 0.848 & - \\
\hline 3 & Bilgi ve Kaynak & 0.702 & 0.542 \\
\hline 4 & Firsat & 0.927 & - \\
\hline
\end{tabular}

Oran ölçek için yapılan çalışmalarda ise, 3. boyut olan "Bilgi ve Kaynak" boyutunda Pearson korelasyon katsayısının dikkate alınması gerekmektedir. Bu boyut için Pearson katsayısı .542 olarak hesaplanmıştır ve bu sayı sınır değer olan .70'in altındadır; fakat, daha önce belirtildiği gibi ölçek geliştirme aşamasında bu kabul edilebilir bir değerdir. Bu nedenle, ölçek belirtilen faktörler çerçevesinde ele alınarak analizlere devam edilecektir.

\section{MTMM (Çoklu Özellik Çoklu Yöntem) Matrisi}

İfadelerin arındırılması ve faktör analizinin ardından, ölçeğin geçerlilik ve güvenirliğini daha derinlemesine irdeleyebilmek için, bir Multi-Trait-Multi-Method Matrisi (Çoklu Özellik Çoklu Yöntem Matrisi) oluşturulmuştur. MTMM Matrisi ölçeğin yapısal geçerliliğini test etmek için kullanılmaktadır ve çeşitli korelasyon istatistiklerini özetleyen bir matristir. MTMM Matrisinin öncelikli varsayımı ölçülecek birden fazla özellik ve yöntem olduğudur. Ayrıca, kare ve simetrik bir matris olmasından ötürü yalnızca yarısı ele alınarak analiz edilir. Aşağıdaki matriste, 
yöntem olarak veri toplama metodları olan oran ölçek ve aralık ölçek, özellik olarak ise ortaya çıkan faktörler kullanılmıştır.

Bir korelasyon setinin kullanılmadığı tek yer güvenirlik köşegeni de denilen ana köşegendir. Normalde buradaki korelasyon değerlerinin hepsinin 1 olması gerekirken Test-Yeniden Test veya Örneklemi İkiye Bölme veya Cronbach Alpha kullanılarak elde edilen iki farklı ölçümün korelasyonlara burada yer verilir.

MTMM Matrisi 1959 yılında Campbell ve Fiske tarafından geliştirilmiştir ve yorumlanırken dikkat edilmesi gereken birkaç temel prensip bulunmaktadır. Öncelikle, güvenirlik köşegenindeki tüm değerlerin matristeki en yüksek değerler olması gerekmektedir. Mavi köşegen güvenirlik köşegenidir ve ölçekteki her bir boyutun Cronbach Alpha güvenirlik derecesini temsil eder. Güvenirlik, benzer yöntemle benzer özelliğin ölçülmesi için yapılan iki denemenin benzerlik derecesini vermektedir. Bu nedenle de matristeki en yüksek dereceler bu köşegende olmalıdır. Burada belirtilmesi gereken bir nokta şudur: matriste bir korelasyon setinin kullanılmadığı tek yer güvenirlik köşegenidir çünkü normalde bu değerlerin hepsinin "1" olması gerekmektedir (tek-yöntem-tek-özellik korelasyonları). Burada ise, TestYeniden Test, Örneklemi İkiye Bölme veya Cronbach Alfa kullanılarak elde edilen iki farklı ölçümün korelasyonları verilmektedir (İki ifadeden oluşan faktörlerde Cronbach Alfa yerine Pearson katsayısı kullanılmıştır). Mavi köşegende görülen değerler- $.878, .865, .737, .906, .916, .848, .542, .927$ - genellikle .70 üzerindedir ve en yüksek değerlerdir; fakat, oran ölçekle elde edilen "Bilgi ve Kaynak" boyutuna ait değer .542 olarak görülmektedir. Ayrıca, Resmi Güç (Yöntem 1) - Resmi Güç (Yöntem 2) ve Bilgi ve Kaynak (Yöntem 1)- Bilgi ve Kaynak (Yöntem 2) korelasyonları özelliklerin kendileri ile olan korelasyonlarından yüksektir. Bu 3 nokta güvenirlik köşegenindeki sorunlar olarak belirtilebilir.

Ölçeğin geçerliliğini test edebilmek için bir diğer gereklilik, geçerlilik köşegenindeki değerlerin sıfırdan farklı olması ve yüksek değerler olmasıdır (Campbell ve Fiske 1959). Geçerlilik köşegeni aynı özelliği ölçen farklı yöntemler arasındaki korelasyonları göstermektedir ve bu nedenle yüksek olmaları beklenmektedir. Matristeki yeşil köşegen geçerlilik köşegenidir ve tüm değerlerin .70'den yüksek olması yakınsama geçerliliği göstergesidir.

Ayırt edici geçerlilik testi için öncelikle hetero-yöntem bloğu içinde bakıldığında tüm geçerlilik katsayıları aynı kolondaki ve aynı satırdaki tüm değerlerden büyük olmalıdır çünkü farklı kavramlar arasındaki korelasyonların kavramların kendileriyle korelasyonların düşük olması beklenmektedir. Bizim matrisimizde bu koşul sağlanmaktadır. Ayırt edici geçerlilik için diğer kriterler ise, heteroözellik-tekyöntem üçgenlerindeki geçerlilik katsayılarının üçgendeki tüm diğer katsayılardan büyük olması ve her üçgende aynı tip ilişki ve aşağı yukarı aynı katsayı oranları gözlemleniyor olmaktır (Campbell ve Fiske 1959). Bu iki kriter de bizim matrisimizdeki heteroözellik-tekyöntem ve heteroözellikheteroyöntem üçgenleri için sağlanmaktadır.

Resmi Güç (Yöntem 1) ve Resmi Güç (Yöntem 2) arasındaki görece yüksek korelasyon, ölçümde yöntemlerin anlamlı bir fark yaratmadığını göstermektedir; fakat, genel olarak bakıldığında, matris yakınsama geçerliliği ve ayırt edici geçerlilik koşullarını sağlamaktadır. Ayrıca, ek olarak, ölçeğin nomolojik geçerliliği de bir sonraki bölümde ele alınmaktadir.

Tablo 7. MTMM Matrisi

\begin{tabular}{|c|c|c|c|c|c|c|c|c|c|}
\hline & & \multicolumn{4}{|c|}{ Yöntem 1 (Aralık Ölçek) } & \multicolumn{4}{|c|}{ Yöntem 2 (Oran Ölçek) } \\
\hline & & $\begin{array}{l}\text { Resmi } \\
\text { Güç }\end{array}$ & $\begin{array}{l}\text { Gayr1 Resmi } \\
\text { Güç }\end{array}$ & $\begin{array}{l}\text { Bilgi ve } \\
\text { Kaynak }\end{array}$ & Firsat & $\begin{array}{l}\text { Resmi } \\
\text { Güç }\end{array}$ & $\begin{array}{c}\text { Gayrı } \\
\text { Resmi Güç }\end{array}$ & $\begin{array}{l}\text { Bilgi ve } \\
\text { Kaynak }\end{array}$ & Firsat \\
\hline \multirow{4}{*}{$\begin{array}{c}\text { Yöntem } \\
1\end{array}$} & Resmi Güç & 0.878 & & & & & & & \\
\hline & $\begin{array}{l}\text { Gayr1 Resmi } \\
\text { Gücc }\end{array}$ & 0.660 & 0.865 & & & & & & \\
\hline & $\begin{array}{l}\text { Bilgi ve } \\
\text { Kaynak }\end{array}$ & 0.613 & 0.590 & 0.737 & & & & & \\
\hline & Firsat & 0.605 & 0.663 & 0.559 & 0.906 & & & & \\
\hline \multirow{4}{*}{$\begin{array}{l}\text { Yöntem } \\
2\end{array}$} & Resmi Güç & 0.910 & 0.672 & 0.634 & 0.658 & 0.916 & & & \\
\hline & $\begin{array}{l}\text { Gayr1 Resmi } \\
\text { Güç }\end{array}$ & 0.703 & 0.783 & 0.631 & 0.534 & 0.785 & 0.848 & & \\
\hline & $\begin{array}{l}\text { Bilgi ve } \\
\text { Kaynak }\end{array}$ & 0.424 & 0.491 & 0.807 & 0.467 & 0.518 & 0.676 & 0.542 & \\
\hline & Firsat & 0.575 & 0.578 & 0.560 & 0.900 & 0.725 & 0.628 & 0.621 & 0.927 \\
\hline
\end{tabular}

\section{Nomolojik Geçerlilik}

Nomolojik geçerlilik yapısal geçerliliğin bir bölümüdür ve ölçülen bir kavramın başka kavramlarla ilişkisinin geçmiş araştırmalardaki bulgulara kıyasla ne derece benzer çıktığını ifade eder ve literatürle tutarlılık göstergesidir. Daha önce belirtildiği gibi, ankete eklenen sorular ile nomolojik geçerliliğin test edilmesi amaçlanmıştır. Eklenen ifadeler kısa bir literatür taraması ile oluşturulmuştur. Organizasyonun hiyerarşik yapısı ile ilgili sorular şunlardır: "Çalıştığım kurumda hiyerarşik kademe sayısı fazladır”, "Çalıştığım kurumda karar verme yetkisi en tepede toplanmıştır." ve "Çalıştığım 
kurumda, yazılı kurallar ve prosedürler mevcuttur.”. İş tatmini için eklenen ifadeler ise şunlardır: "İşimin bana uygun olduğunu düşünüyorum.", "Yaptığım işten keyif alıyorum.” ve "Bu işte çalışmayı sürdürmek isterim".

Güçlendirme ve hiyerarşik yapı arasındaki korelasyon -.222 olarak hesaplanmıştır ve .05 seviyesinde anlamlıdır. Bu değer, yüksek bir korelasyon olmamasına karşın, beklenildiği gibi güçlendirme ve hiyerarşik yapı arasında negatif bir ilişki göstermektedir. İş tatmini ile güçlendirme arasındaki korelasyon ise .690 olarak hesaplanmıştır ve .01 seviyesinde anlamlıdır. Bu korelasyon nomolojik geçerlilik için bir destek oluşturmaktadır. Burada, bu sonuçların sorulan ifadeler çerçevesinde anlamlı olduğunu ve daha güvenilir ölçeklerle test edilmesi gerektiğini vurgulamakta fayda vardir.

\section{Sonuç ve Değerlendirme}

$\mathrm{Bu}$ araştırmanın amacı varolan bir kavrama yeni bir bakış açısı getirmek, ölçek geliştirme metodolojisine örnek sunmak ve bu bağlamda yeni bir ölçek ortaya koymaktır. Nicel ve nitel veri toplama yöntemleri birlikte kullanılarak geçerli ve güvenilir bir yapısal güçlendirme ölçeği oluşturmaya çalışılmıştır. Analiz sonuçlarına göre elde edilen güçlendirme ölçeği ekte (Ek 2) sunulmaktadır.

Çalışma nitel ve nicel araştırma kısımlarından oluşmaktadır. Örneklemlerin sayısı göz önünde bulundurulduğunda daha geniş bir kitleyle tekrarlanması çalışmanın genellenebilirliğini attıracaktır. Derinlemesine mülakatta yalnızca bir kişi ile görüşülmüş olması çalışmanın kısıtları arasında sayılabilir. Ayrıca ifade sınıflandırılması aşamasında hakem olarak doktora öğrencilerine başvurulmuş olması çalışmanın bir diğer kısıtıdır. İlgili alanda daha uzman hakemlerden destek almak da çalışmanın güvenilirliğine olumlu katkı sağlayacaktır.

Güçlendirme yeni bir kavram olmamakla birlikte, bu çalışma kapsamında yapısal/ bağlamsal bir süreç olarak ele alınmıştır. Bu nedenle, bu yaklaşımın yeni araştırma alanları açması ve ölçek geliştirme metodolojisine bir örnek oluşturması hedeflenmiştir. Literatürde, farklı dillerde ve kültürlerde geliştirilmiş güçlendirme ölçeklerinin Türkçe'ye uyarlanmasına yönelik pek çok çalışma mevcuttur. Bu araştırmalar genellikle ölçeklerin Türkçe'ye tercümesi ve güvenilirlik çalışmalarıyla sınırlıdır. Bu bağlamda, bu çalışma, yerel verileri geçmiş literatürle birleştirirerek yeni bir ölçek ortaya koymakta ve güçlendirme kavramının bu kültürde nasıl algılandığına dair bir örnek teşkil etmektedir.

Çalışanların güçlendirilmesi günümüz örgütleri için kaçınılmaz bir gereksinimdir. Özellikle yataylaşan organizasyon yapılarıyla birlikte, yöneticilerin kontrol alanları genişlemekte ve bu nedenle delegasyonun önemi artmaktadır. Doğru güçlendirme ve koordinasyon hem yöneticilerin işlerini kolaylaştırmakta, hem de çalışan motivasyonunu arttırmaktadır. Bu nedenle güçlendirme kavramının iyi anlaşılması ve doğru uygulanması hem organizasyonlar hem de çalışanlar için olumlu sonuçlar sağlayacaktır.

$\mathrm{Bu}$ araştırmayla çalışanların güçlendirme kavramından beklentileri ve hangi alt boyutları ilişkili gördükleri bir kez daha ortaya konmuştur. Güçlendirme kavramının doğru uygulanabilmesi ve yönetilebilmesi için öncelikle doğru anlaşılması gerekmektedir. Bu nedenle, çalışanların güçlendirme kavramını nasıl tanımladıkları, bir bakıma, üstlerinden ve çalıştıkları kurumlardan neler beklediklerini göstermektedir.

Son olarak, çalışmada, geçmiş literatürün aksine, güçlendirmenin beş yerine dört boyut altında toplandığı görülmüştür. İleriki çalışmalarda, daha geniş örneklemlerle, güçlendirme ölçeğinin yapısının tekrar incelenmesi ve bu farklılığın neden kaynaklandığının araştırılması önerilmektedir. 


\section{KAYNAKÇA}

Altman, D.G. 1991. Practical statistics for medical research. London: Chapman and Hall.

Arnold, J. A., Arad, S., Rhoades, J.A. ve Drasgow, F. 2000. "The empowering leadership questionnaire: The construction and validation of a new scale for measuring leader behaviors". Journal of Organizational Behavior, 21, 249-269.

Bakan, İ. 2004. Çăğdaş Yönetim Yaklaşımları (İlkeler, Kavramlar ve Yaklaşımlar). Beta Yayıncılık, İstanbul.

Campbell, D. T. ve Fiske, D. W. 1959. "Convergent and Discriminant Validation by the Multitrait-Multimethod Matrix”. Psychological Bulletin, 56(2), 81-110.

Chandler, G.E. 1986. The relationship of nursing work environment to empowerment and powerlessness. Unpublished doctoral dissertation, University of Utah.

Cohen, J. 1960. "A coefficient of agreement for nominal scales". Educational and Psychological Measurement, $20,37-$ 46.

Çöl, G. 2008. “Algılanan güçlendirmenin işgören performansı üzerine etkileri”. Doğuş Üniversitesi Dergisi, 9(1), 31-46.

Cunningham, I., Hyman, J. ve Baldrig, C. 1996. "Empowerment : the power to do what?". Industrial Relations Journal, 27(2), 143-154.

Dobbs, John H. 1993. “The empowerment environment”. Training and Development. February: 55-57.

Greco, P., Laschinger, H.K.S. ve Wong, C. 2006. "Leader Empowering Behaviors, Staff Nurse Empowerment and Work Engagement/Burnout". Nursing Leadership, 19(4), 41-56.

Hales, C. ve Klidas, A. 1998. "Empowerment in five-stars hotels : choice, voice or rhetoric?". International Journal of Contemporary Hospitality Management, 10(3), 88-95.

Hamel, G. ve Prahalad, C.K. 2002. Competing for the Future. McGraw-Hill Education.

Harari, 0. 1993. "Stop Empowering Your People". Management Review, 82, 11, 26-29.

Jun, J. K. ve Lee, C.W. 2000. "A Study of Psychological Empowerment of Hotel Employees in South Korea". In: Proceedings From The 6th Asia Pacific Tourism Association Conference. Phuket, Thailand: Prince of Sonkla University.

Kanter, R. M., 1977. Men and Women of the Corporation. New York City: Basic Books Inc.

Kılıç, S. 2015. "Kappa Testi”. Journal of Mood Disorders, 5(3), 142-144.

Konczak, L. J., Stelly, D. J. ve Trusty, M. L. 2000. "Determining and measuring empowering leader behaviors: Development of an upward feedback instrument”. Educational and Psychological Measurement, 60(2), 301313.

Landis, J. ve Koch, G. 1977. "The measurement of observer agreement for categorical data”. Biometrics, 33, $159-74$.

Laschinger, H. K. S., Finegan J., Shamian J. ve Wilk P. 2001. "Impact of Structural and Psychological Empowerment on Job Strain in Nursing Work Settings". Journal of Nursing Administration, 31, 260-272.

Leslie, D., Holzhalb, C., ve Holland, T.P. 1998. "Measuring staff empowerment: Development of a worker empowerment scale". Research on Social Work Practice, 8(2), 212-222.

London, M. 1993. "Relationships between career motivation, empowerment and support for career development". Journal of Ocuupational and Organizational Psychology, 66, 55-69.

McHugh, M. L. 2012. "Interrater reliability: the kappa statistic”. Biochemia Medica, 22(3), $276-82$.

Morgan, D. L. 1997. Focus Group as Qualitative Research. Thousand Oaks, California: Sage Publications.

Netemeyer, R.G., Bearden W. O. ve Sharma, S. 2003. Scaling Procedures: Issues and Applications. Sage Publications.

Peter, J. P. 1979. "Reliability: A Review of Psychometric Basics and Recent Marketing Practices". Journal of Marketing Research, 26 (February), 6-17.

Randolph, W. A. 1995. "Navigating the Journey to Empowerment”. Organizational Dynamics, 23, 4, 19-32.

Savery, L.K. ve Luks, A.J. 2001. "The relationship between empowerment, job satisfaction and reported stress levels: some Australian evidence". Leadership \& Organization Development Journal, 2293, 97-104.

Sharma, M. ve Kaur,G. 2011. "Workplace Empowerment And Organizational Effectiveness: An Empirical Investigation Of Indian Banking Sector". Academy of Banking Studies Journal, Volume 10, Number 2, 2011.

Spreitzer, G. M. 1995. "Psychological Empowerment In The Workplace: Dimensions, Measurement and Validation". Academy of Management Journal, 38 (5), 1442-1465.

Spreitzer, G. M., Kizilos, M. A. ve Nason, S. W. 1997. "A dimensional analysis of the relationship between psychological empowerment and effectiveness, satisfaction and strain”. Journal of Management, $23,5$.

Swenson, D. X. 1997. "Requisite Conditions for Team Empowerment”. Empowerment in Organizations. 5(1).

Tandoğan, H. T.2002. "Dönüştürücü ve İşgördürücü Liderliğin Kontrol Odağına Bağlı Olarak Personel Güçlendirmeye Etkisi”. Yüksek Lisans Tezi. Marmara Üniversitesi Sosyal Bilimler Enstitüsü, İstanbul.

Ton, İ. A. 2008. The Effect of Individualism- Collectivism (IC) and Trust on Workplace Empowerment. Doktora Tezi. Marmara Üniversitesi, İstanbul.

Wall, T. D., Cordery, J. L. ve Clegg, C. W. 2002. "Empowerment, Performance and Operational Uncertainty: A Theoretical Integration”. Applied Psychology, An International Review, 51(1), 146-169. 


\section{EK1. Katılımcılara Dağıtılan Anketteki İfadeler}

1. Yöneticim kendi kararlarımı vermem konusunda bana güvenir.

2. Yöneticim bana gerektiğinde değişiklik yapmam için yetki verir.

3. Kendi işim hakkında karar verme yetkisine sahip değilim.

4. Yöneticim bana verdiği işten beni sorumlu tutar.

5. İşimi nasıl yapacağım konusunda imtiyaz (özerklik) sahibiyim.

6. Yöneticim bana sorumluluğumla eşdeğer düzeyde yetki devretmez.

7. Devam etmeden önce, en basit kararların bile yöneticiler tarafından kontrol edilmesi gerekir.

8. Problemler ortaya çıktığında, yöneticim, ne yapılacağını söylemektense, çözüm üretmem için beni destekler.

9. Yöneticilerim işleri kontrol edebilecek yeterliliğe sahip olduğumu düşünür.

10. Bir problemin çözümü için yöneticilerim bana başvurur.

11. Bir problemin çözümü için iş arkadaşlarım bana başvurur.

12. İşimde bazen pozisyonumun gerekliliklerinin üstünde görevler yürütüyorum.

13. Mesleğimi icra ederken bana esneklik tanınır.

14. Üst yönetimin benimsediği değerler hakkında bilgi sahibiyim.

15. Üst yönetimin şirket için koyduğu hedefler hakkında bilgi sahibi değilim.

16. Yöneticim kaliteli sonuçlara ulaşmamı sağlayacak bilgileri benimle paylaşır.

17. Bölüm hedeflerini tutturmak için yöneticilerle ortaklaşa çalışırız.

18. Bir problemin çözümü için şirketteki başka bölümlerin yöneticilerinden yardım alabiliyorum.

19. Gerektiğinde üst yönetimle beraber toplantılara katılabiliyorum.

20. İşimin gereklerini yerine getirmek için yeterli zamana sahip değilim.

21. İşimin gereklerini yerine getirmem için her türlü kaynak bana sunulur.

22. İşimde yeni bilgi ve beceriler edinebilme şansına sahibim.

23. Yöneticim bana yeni yetenekler kazanmam için firsatlar sunar.

24. İşimde gerekli yerlerde her zaman eğitim desteği sunulur.

\section{EK2. Elde Edilen Güçlendirme Ölçeği}

- Yöneticim kendi kararlarımı vermem konusunda bana güvenir.

- Yöneticim bana gerektiğinde değişiklik yapmam için yetki verir.

- İşimi nasıl yapacağım konusunda imtiyaz (özerklik) sahibiyim.

- Yöneticim işleri kontrol edebilecek yeterliliğe sahip olduğumu düşünür.

- Bir problemin çözümü için yöneticilerim bana başvurur.

- Bir problemin çözümü için iş arkadaşlarım bana başvurur.

- Mesleğimi icra ederken bana esneklik tanınır.

- Üst yönetimin benimsediği değerler hakkında bilgi sahibiyim.

- Yöneticim kaliteli sonuçlara ulaşmamı sağlayacak bilgileri benimle paylaşır.

- Bölüm hedeflerini tutturmak için yöneticilerle ortaklaşa çalışırız.

- Bir problemin çözümü için şirketteki başka bölümlerin yöneticilerinden yardım alabiliyorum.

- Gerektiğinde üst yönetimle beraber toplantılara katılabiliyorum.

- İşimin gereklerini yerine getirmem için her türlü kaynak bana sunulur.

- İşimde yeni bilgi ve beceriler edinebilme şansına sahibim.

- Yöneticim bana yeni yetenekler kazanmam için firsatlar sunar.

- İşimde gerekli yerlerde her zaman eğitim desteği sunulur. 